\title{
PEMANFAATAN BUAH MENGKUDU TERHADAP KUALITAS MINYAK JELANTAH SEBAGAI SUMBER BELAJAR KIMIA DI SMA KUANTAN SINGINGI
}

\author{
Sri Rahayu ${ }^{1}$, Fitri Refelita ${ }^{2}$ \\ ${ }^{1}$ Prodi Pendidikan Kimia Fakultas Tarbiyah dan Keguruan \\ e-mail: Srirahayuyu10@gmail.com \\ ${ }^{2}$ Prodi Pendidikan Kimia Fakultas Tarbiyah dan Keguruan \\ Universitas Islam Negeri Sultan Syarif Kasim Riau
}

\begin{abstract}
Abstrack
Cooking oil is one food that is very needed by the whole society. The rising price of cooking oil in among society with low economics, is one of the factors causing the repeated use of cooking oil (Waste cooking oil). Using of waste cooking oil can cause poisoning, cancer and others. This research aimed to know the persentage reduction in acid number and water content, also organoleptic of the oil produced. The methods of waste cooking oil can be done by giving antioxidant to the oil. Noni fruit is one of the plant that be rich of antioxidant. 50 gram simplisia of noni added to $250 \mathrm{ml}$ waste cooking oil of packadge and bulk oil. The methods of acid number by alkalimetri and measurement of water content using oven. The organoleptic tests carried out by favorite level from 25 panelists. The results of this research showed that persentage of reduction in packpage and bulk oil's acid number were $28 \%$ and $25 \%$. Whereas for persentage of reduction water content from each oil were $75 \%$ and $71.42 \%$. The favorite level of color, odor and flavor were $99 \%, 76 \%$ and $89 \%$. The results of the questionnaire about the feasibility of video in terms of content and appearance was $84.375 \%$, which was included in the excellent category.
\end{abstract}

Keywords: Waste Cooking Oil, Noni Fruit, Water Content, Acid Number and Organoleptic Tests.

\section{PENDAHULUAN}

Penggunaan minyak goreng di Indonesia telah menjadi kebutuhan pokok bagi manusia, meskipun menggoreng hanyalah merupakan salah satu dari sekian banyak cara memasak makanan, karena minyak goreng hanya berfungsi sebagai medium penghantar panas, menambah rasa gurih, menambah nilai gizi dan kalori dalam bahan pangan.

Minyak goreng tidak hanya digunakan untuk kebutuhan sehari-hari saja, tetapi minyak goreng banyak digunakan pada makanan-makanan komersial yang diperdagangkan. Harga minyak goreng yang melambung tinggi menyulitkan masyarakat, sehingga dirasa perlu dilakukan penghematan pemakaiannya. Penghematan dapat dilakukan dengan menggunakan minyak goreng tersebut secara berulang-ulang, terutama oleh pedagang gorengan pinggir jalan, dimana minyak goreng sering dipakai berulang kali.
Pemakaian minyak goreng yang berulang kali bila ditinjau dari segi medis maupun klinis hal ini akan berbahaya bagi kesehatan, karena minyak goreng jelantah yang mengalami pemanasan berulang pada suhu tinggi akan lebih cepat proses perubahan minyaknya. Perubahan yang terjadi seperti perubahan kimia yang tampak dari meningkatnya bilangan asam, sehingga dapat menyebabkan kerusakan gizi. Selain mengakibatkan perubahan kimia juga dapat mengakibatkan terjadinya perubahan fisika seperti perubahan kadar air, warna, bau dan rasa. Selain itu, minyak yang secara berulangulang digunakan, bahkan sampai berwarna coklat tua atau hitam dapat menimbulkan dampak negatif bagi yang mengkonsumsinya, yaitu menyebabkan berbagai gejala keracunan, seperti pusing, mual-mual dan muntah [1].

Mengkudu adalah salah satu sumber antioksidan yang dapat menetralisir senyawasenyawa radikal bebas yang terdapat di dalam 
minyak, selain itu dengan adanya senyawa linoleat pada mengkudu juga dapat dimanfaatkan untuk menekan laju pengaruh trans fatty acid dalam mengurangi kadar HDL (High Density Lipoprotein) yang dapat menaikkan kolesterol dalam tubuh. Mengkudu sebagai buah-buahan yang selama ini dikenal sebagai buah obat bagi beberapa penyakit yang cukup dekat dengan kolesterol dalam tubuh seperti jantung, darah tinggi dan stroke. Beberapa zat penting yang terkandung di dalam mengkudu sehingga dapat menjernihkan minyak jelantah dapat digolongkan menjadi dua kelompok, yaitu kelompok antioksidan yang terdiri dari xeronin, proxeronin dan asam askorbat, serta kelompok pemerkaya kandungan yang terdiri dari asam linoleat, $\beta$ karoten dan caprylit acid [2].

Berdasarkan kelebihan yang dimiliki mengkudu, peneliti menduga bahwa mengkudu memiliki manfaat terhadap penurunan bilangan asam, kadar air dan uji organoleptik minyak jelantah, sehingga hasil yang didapat aman untuk dipakai dan kualitasnya bisa kembali (minimal mendekati) kualitas minyak goreng yang masih baru. Oleh sebab itu, peneliti tertarik untuk melakukan penelitian yang nantinya dapat dijadikan sebagai sumber belajar pada materi Lipid.

Berdasarkan latar belakang di atas, peneliti tertarik untuk membuat penelitian dengan judul "Pemanfaatan Buah Mengkudu terhadap Penurunan Bilangan Asam, Kadar Air dan Uji Organoleptik Minyak Jelantah sebagai Sumber Belajar Kimia pada Materi Lipid di Sekolah Menengah Atas Kabupaten Kuantan Singingi".

\section{METODE PENELITIAN}

\section{Waktu dan Tempat Penelitian}

Penelitian ini dilakukan pada bulan Maret s/d April 2016. Pengukuran bilangan asam dan kadar air minyak dilakukan di Laboratorium Pendidikan Kimia Fakultas Tarbiyah dan Keguruan Universitas Islam Negeri Sultan Syarif Kasim Riau. Kelayakan penelitian sebagai sumber belajar Kimia pada meteri Lipid dilakukan di SMA Negeri 1 Singingi, SMA Negeri 1 Singingi Hilir dan
MAN Teluk Kuantan. Sedangkan uji organoleptik minyak jelantah setelah ditambahkan mengkudu dilakukan di Muara Lembu, Kecamatan Singingi, Kabupaten Kuantan Singingi.

\section{Subjek dan Objek Penelitian}

Subjek dalam penelitian ini adalah guru kimia se-kabupaten Kuantan Singingi yang diambil dari tiga sekolah, yaitu SMA Negeri 1 Singingi, SMA Negeri 1 Singingi Hilir dan MAN Teluk Kuantan, serta masyarakat Muara Lembu. Objek dari penelitian ini adalah pemanfaatan buah mengkudu terhadap penurunan bilangan asam, kadar air dan uji organoleptik minyak jelantah sebagai sumber belajar kimia pada materi lipid di Sekolah Menengah Atas.

\section{Sampel Penelitian}

Sampel yang digunakan dalam penelitian ini adalah dua jenis minyak jelantah yang berasal dari minyak curah dan minyak kemasan. Kedua jenis minyak ini diberikan perlakuan sama, yaitu digunakan untuk menggoreng tahu sebanyak 6 kali penggorengan.

\section{Penentuan Sampel Uji}

Penentuan sampel uji dilakukan menggunakan metode purposive sampling, dimana sampel uji dipilih berdasarkan jenis minyak goreng yang banyak digunakan oleh ibu-ibu di desa Muara Lembu, Kabupaten Kuantan Singingi menggunakan teknik wawancara.

\section{Alat dan Bahan}

\section{A. Alat}

Alat yang digunakan adalah gelas kimia, magnetik stirrer, hotplate, oven, penyaring Buchner, saringan kelapa, penangas air, corong, neraca analitik, tabung reaksi, termometer, pisau, batang pengaduk, cawan penguap, erlenmeyer, gelas ukur, pipet tetes dan seperangkat alat titrasi.

B. Bahan

Bahan yang digunakan adalah minyak kemasan baru, minyak jelantah kemasan, minyak curah baru, minyak jelantah curah, indikator pp, mengkudu, $\mathrm{KOH} 0,1 \mathrm{~N}$, alkohol $96 \%$ dan aquades. 


\section{Prosedur Kerja}

\section{A. Persiapan Minyak Jelantah}

Sampel minyak goreng jelantah diambil dari minyak kemasan dan minyak curah baru yang dibeli di pasar daerah Panam, Pekanbaru. Kedua jenis minyak ini diberikan perlakuan sama, yaitu digunakan untuk menggoreng tahu selama $6 \quad$ kali penggorengan.

B. Pembuatan Simplisia Mengkudu

Mengkudu yang telah matang dipetik dari pohon, kemudian dicuci, dipotong-potong berbentuk dadu dan dioven pada suhu $40^{\circ} \mathrm{C}$ selama 3 jam [3].

C. Penjernihan Minyak Jelantah menggunakan Sari Mengkudu

Disiapkan masing-masing minyak jelantah $\pm 250 \mathrm{ml}$, selanjutnya disaring untuk menghilangkan sisa-sisa makanan. Minyak dimasukkan ke dalam wadah penyimpanan dan untuk setiap wadah ditambahkan simplisia mengkudu sebanyak 50 gram. Diaduk menggunakan magnetik stirrer, kemudian didiamkan selama 15 menit. Setelah itu dipanaskan hingga suhu $50^{\circ} \mathrm{C}$ sambil diaduk menggunakan batang pengaduk. Dipertahankan hingga minyak berwarna jernih, kemudian disaring menggunakan penyaring Buchner [4].

D. Uji Kualitas

1) Uji kualitas minyak kemasan

2) Uji kualitas minyak curah

3) Uji kualitas minyak jelantah yang berasal dari minyak kemasan dan minyak curah sebelum ditambahkan dengan simplisia mengkudu

4) Uji kualitas minyak jelantah yang berasal dari minyak kemasan dan minyak curah setelah ditambahkan

dengan simplisia mengkudu. Untuk penentuan kualitas ini parameter yang diukur meliputi kadar air dan bilangan asam.

Kadar air

Kadar air minyak yang telah ditetapkan SNI maksimal sebanyak 0,15\% (b/b) [5]. Penentuan kadar air minyak dapat dilakukan dengan cara sebagai berikut:
Ditimbang $10 \mathrm{~g}$ untuk masing-masing minyak kemasan, minyak curah, minyak jelantah dan minyak jelantah hasil rendaman dengan simplisia mengkudu, kemudian dioven pada suhu $105^{\circ} \mathrm{C}$ sampai berat konstan, selanjutnya ditimbang. Pengurangan berat minyak dinyatakan sebagai berat air yang menguap dari minyak [6].

\section{Bilangan Asam}

$$
\text { kadar air }=\frac{A-B}{A} \times 100 \%
$$

Masing-masing minyak ditimbang sebanyak $5 \mathrm{~g}$, kemudian ditambah $50 \mathrm{ml}$ alkohol 96\%, dipanaskan selama 10 menit dalam penangas air suhu $40^{\circ} \mathrm{C}$ sambil diaduk. Alkohol berfungsi untuk melarutkan asam lemak. Setelah didinginkan kemudian dititrasi dengan $\mathrm{KOH} \quad 0,1 \mathrm{~N}$ menggunakan 2 tetes indikator pp sampai tepat warna merah jambu [7]. Bilangan asam yang telah ditetapkan SNI maksimal sebanyak 0,6 mg KOH/g [8].

$$
=\frac{\mathrm{ml} \mathrm{KOH} \mathrm{x} \mathrm{N} \mathrm{KOH} \mathrm{x} \mathrm{BM} \mathrm{KOH}}{\text { Bobot Contoh (gram) }}
$$

Keterangan:

$\mathrm{ml} \mathrm{KOH} \quad=$ jumlah $\mathrm{ml} \mathrm{KOH}$ untuk titrasi

$\mathrm{N} \mathrm{KOH}=$ normalitas larutan $\mathrm{KOH}$

$\mathrm{BM} \mathrm{KOH}=$ bobot molekul $\mathrm{KOH}(56,1)$

Bobot Contoh $=$ bobot sampel (gram)

E. Uji Organoleptik

Warna

Diambil minyak jelantah dari minyak kemasan dan minyak curah yang telah ditambahkan mengkudu secukupnya dan diletakkan di wadah yang bersih dan kering. Selanjutnya diamati warnanya. Jika warna minyak jelantah setelah ditambahkan mengkudu terlihat lebih jernih, berarti mengkudu bermanfaat terhadap minyak jelantah.

\section{Bau}

Masing-masing minyak jelantah yang telah ditambahkan mengkudu dimasukkan ke dalam wadah tertutup, dikocok lalu dibuka, kemudian dicium pada jarak kira-kira $5 \mathrm{~cm}$ dari hidung dan kemudian dikebaskan ke arah hidung [9]. 
Rasa

Salah satu minyak jelantah yang telah ditambahkan mengkudu digunakan untuk menggoreng tahu. Tahu hasil gorengan minyak tersebut dimakan untuk mengetahui apakah tahu tersebut tetap disukai atau tidak. Sebelum panelis memakan tahu, panelis diharuskan minum air putih terlebih dahulu [10].

\section{Penilaian}

Untuk penilaian, peneliti memperlihatkan minyak hasil penjernihan dan video penjernihan minyak menggunakan mengkudu serta pengukuran bilangan asam dan kadar airnya, selanjutnya peneliti meminta tanggapan guru mengenai kelayakan penelitian yang dikemas dalam bentuk video yang meliputi isi dan penampilannya yang diberikan kepada guru kimia di 3 SMA Kabupaten Kuantan Singingi, yaitu satu orang guru kimia di SMA Negeri 1 Singingi, satu orang guru kimia di SMA Negeri 1 Singingi Hilir dan dua orang guru kimia di MAN Teluk Kuantan. Uji Organoleptik diambil dari penilaian 25 panelis tidak terlatih dengan memperlihatkan minyak jelantah setelah ditambahkan mengkudu.

\section{Teknik Pengumpulan Data}

Pengumpulan data awal pada penelitian ini, yaitu dengan menguji kualitas minyak dengan cara mengukur besarnya bilangan asam dan kadar air pada minyak kemasan, minyak curah serta minyak jelantah dari minyak kemasan dan curah sebelum dan setelah ditambahkan mengkudu dengan waktu pendiaman 15 menit. Selanjutnya dilakukan pengumpulan data berupa angket. Angket tersebut akan diisi oleh beberapa orang guru mata pelajaran kimia dari 3 sekolah yang ada di Kabupaten Kuantan Singingi, untuk mengetahui respon guru terhadap video penelitian yang telah dilakukan. Angket uji organoleptik diberikan kepada 25 panel tidak terlatih untuk mengetahui bagaimana pemanfaatan dari buah mengkudu terhadap uji organoleptik minyak jelantah.

Perhitungan persentase penurunan bilangan asam dihitung menggunakan rumus berikut.

\% Penurunan Kadar Bilangan Asam $=\frac{\text { Penurunan Bilangan Asam }(\mathrm{mg} \mathrm{KOH} / \mathrm{g})}{\text { Bilangan Asam Minyak Jelantah }(\mathrm{mg} \mathrm{KOH} / \mathrm{g})} \times 100 \%$

\section{Teknik Analisis Data}

Hasil yang diperoleh dari pengujian bilangan asam dan kadar air ditabelkan serta dianalisis. Kemudian dibandingkan dengan teori yang ada. Secara kuantitatif untuk mengakumulasi semua jawaban responden dari setiap soal ditentukan dari persentase hasil penelitian, yaitu dengan menggunakan rumus [11]:

$\mathrm{P}=\frac{F}{N} \times 100 \%$

\section{HASIL DAN PEMBAHASAN}

\section{A. Persiapan Minyak Jelantah}

Minyak jelantah yang digunakan dalam penelitian ini terdiri dari minyak jelantah yang berasal dari minyak kemasan dan minyak jelantah yang berasal dari minyak curah. Kedua jenis minyak jelantah ini didapatkan dari perlakuan sama yang sebelumnya telah digunakan untuk menggoreng tahu selama enam kali penggorengan.

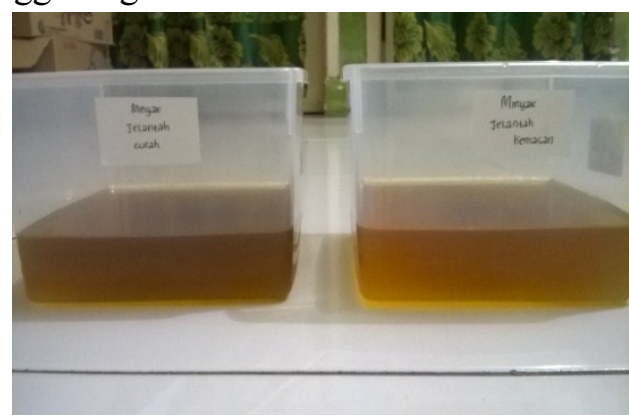

Gambar 1. Minyak Jelantah Curah (Kiri) dan Minyak Jelantah Kemasan (Kanan)

\section{B. Pembuatan Simplisia Mengkudu}

Dalam penelitian ini, mengkudu yang digunakan untuk dijadikan simplisia yaitu mengkudu matang yang baru dipetik dari pohon. Simplisia digunakan untuk menjernihkan minyak jelantah yang telah mengalami kerusakan.

Simplisia mengkudu merupakan salah satu produk olahan kering mengkudu yang diperoleh dengan cara dioven pada suhu $40^{\circ} \mathrm{C}$ selama tiga jam. Selain dioven, simplisia 
mengkudu juga dapat diperoleh melalui pengeringan sinar matahari. Pengeringan ini dilakukan dari jam 08.00-11.00 pagi. Waktu dikeringkan sebaiknya ditutup dengan kain hitam untuk mengurangi kerusakan bahan akibat teriknya sinar yang dapat menurunkan mutu simplisia.

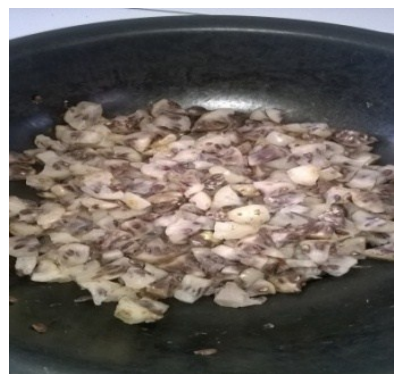

Gambar 2. Simplisia Mengkudu

\section{Penjernihan Minyak Jelantah menggunakan Simplisia Mengkudu}

Minyak goreng jelantah dari minyak kemasan dan minyak curah dijernihkan menggunakan simplisia mengkudu dengan perbandingan 5:1, 250 $\mathrm{ml}$ minyak jelantah dan $50 \mathrm{~g}$ simplisia mengkudu. Perbandingan ini diambil berdasarkan penelitian yang dilakukan oleh Misrawati, dkk., dimana pada perbandingan ini hasil uji organoleptiknya lebih disukai. Selanjutnya campuran diaduk menggunakan magnetik stirrer agar campuran menjadi lebih homogen.

$$
\text { Pengadukan menggunakan }
$$
magnetik stirrer dipilih karena memiliki kecepatan pengadukan dibandingkan dengan menggunakan batang pengaduk biasa. Kecepatan pengadukan juga berpengaruh terhadap kualitas minyak yang telah dijernihkan, semakin cepat waktu kontak, maka semakin banyak asam lemak bebas yang diikat mengkudu [12].

Campuran yang telah diaduk kemudian didiamkan selama 15 menit, selanjutnya dipanaskan hingga suhu $50^{\circ} \mathrm{C}$ sambil diaduk. Suhu $50^{\circ} \mathrm{C}$ digunakan agar tidak merusak kandungan yang ada pada campuran. Penyaringan campuran dilakukan menggunakan penyaring Buchner.

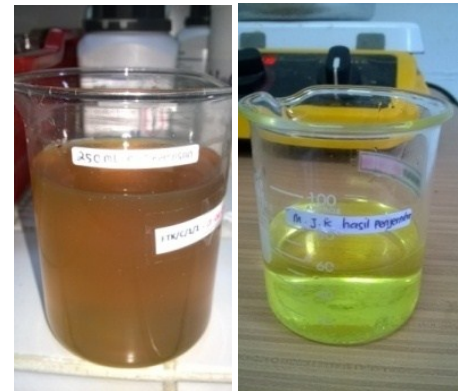

Gambar 3. Minyak Jelantah (Kiri) dan Minyak Hasil Pemurnian (Kanan)

Hasil dari daur ulang jelantah menggunakan buah mengkudu, secara fisik terlihat warna minyak menjadi lebih muda dan bening. Hal ini dikarenakan kotoran yang terdapat dalam jelantah, sebagian terserap oleh mengkudu.

\section{Kualitas Minyak \\ 1. Kadar Air}

Sebelum dilakukan pengujian, minyak diaduk dengan baik. Hal ini dikarenakan air cenderung untuk mengendap, dengan pengadukan diharapkan penyebaran air dalam sampel uji akan merata [13].

Pengujian kadar air dilakukan dengan cara oven terbuka. Tahapan pertama, yaitu menimbang masing-masing minyak sebanyak 10 gram, kemudian dioven pada suhu $105^{\circ} \mathrm{C}$ sampai berat konstan (tetap). Berat konstan didapatkan dari hasil pengulangan penimbangan minyak yang dioven dengan selang waktu $1 / 2$ jam (setiap $1 / 2$ jam dilakukan penimbangan) hingga berat yang didapatkan tidak berubah lagi. Selanjutnya dihitung kadar airnya.

Kadar air yang diukur dari tiga sampel minyak curah, yaitu minyak curah baru, minyak jelantah curah dan minyak jelantah curah hasil pemurnian berturut-turut adalah $0.3 \%, 0.35 \%$ dan $0.1 \%$. Dengan demikian, dapat dihitung nilai penurunan minyak jelantah dan minyak jelantah pemurnian, yaitu sebesar $71.42 \%$. Sedangkan nilai penurunan minyak jelantah dan minyak jelantah pemurnian yang berasal dari minyak kemasan, yaitu $75 \%$. Kadar air dari keenam sampel tersebut, dapat dilihat pada grafik berikut. 


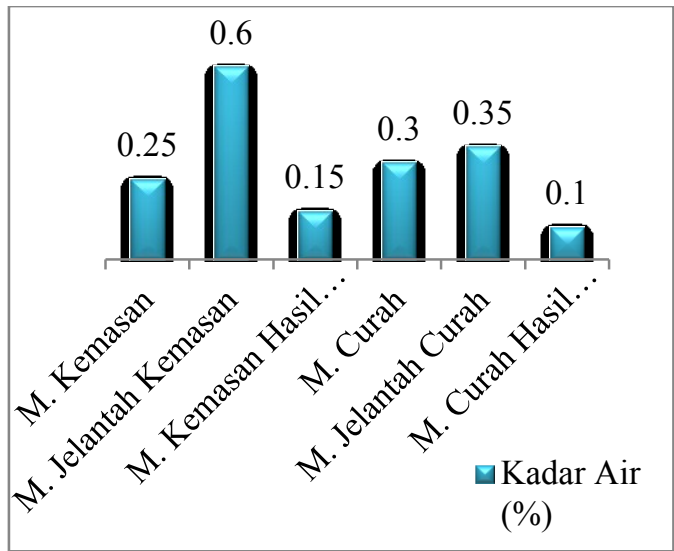

Gambar 4. Grafik Kadar Air (\%)

Tabel 1. Persen Penurunan Kadar Air

\begin{tabular}{|c|c|c|c|c|}
\hline \multirow[t]{2}{*}{ Sampel } & \multicolumn{2}{|c|}{ Kadar Air } & \multirow{2}{*}{$\begin{array}{c}\text { Penuru } \\
\text { nan }\end{array}$} & \multirow{2}{*}{$\begin{array}{c}\% \\
\text { Penuru } \\
\text { nan }\end{array}$} \\
\hline & $\begin{array}{c}\text { M. } \\
\text { Jelantah }\end{array}$ & $\begin{array}{c}\text { M. Jelantah + } \\
\text { Mengkudu }\end{array}$ & & \\
\hline $\begin{array}{l}\text { M. } \\
\text { Kemasan }\end{array}$ & 0.6 & 0.15 & 0.45 & 75 \\
\hline M. Curah & 0.35 & 0.1 & 0.25 & 71.42 \\
\hline
\end{tabular}

Penggunaan mengkudu dalam bentuk simplisia dipilih karena mengkudu terlebih dahulu dikeringkan, sehingga mampu menyerap kadar air secara maksimal.

Tingginya kadar air dalam minyak dapat diperoleh dari bahan makanan yang digoreng, proses saat penggorengan, atau kelembapan udara saat penyimpanan. Selama proses menggoreng, air dalam bahan pangan akan keluar dan diisi oleh minyak goreng sehingga menaikkan kadar air dalam minyak. Dengan adanya air, minyak goreng dapat terhidrolisis menjadi gliserol dan asam lemak bebas. Hidrolisis sangat mudah terjadi dalam minyak dengan asam lemak rendah (lebih kecil $\mathrm{C}_{14}$ ), seperti minyak goreng. Minyak yang telah terhidrolisis, titik asapnya menurun, bahan-bahan menjadi cokelat dan lebih banyak menyerap minyak. Selain itu, reaksi ini akan mengakibatkan ketengikan pada minyak yang digunakan.

Reaksi hidrolisis dapat dipicu dengan menggoreng bahan pangan deep-fat frying. Penggunaan suhu tinggi menghasilkan energi yang terlalu tinggi, yang dapat memecah struktur lemak, lemak akan terhidrolisis membentuk asam lemak bebas dan gliserol. Selanjutnya, ikatan pada gliserol akan pecah sehingga menyebabkan lepasnya dua molekul air dan membentuk senyawa akrolein yang dapat mengiritasi mata serta menimbulkan rasa gatal pada tenggorokan. Pembentukan akrolein dapat dilihat pada gambar berikut.

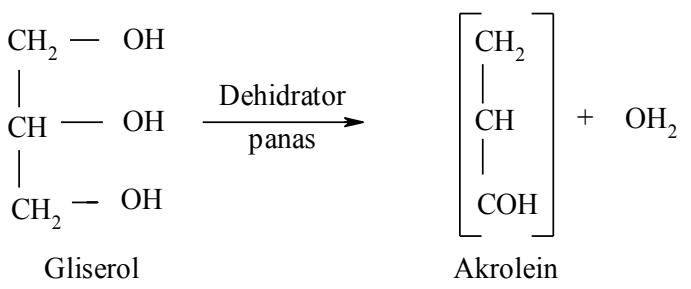

Gambar 5. Reaksi Pemecahan Gliserol membentuk Akrolein

\section{Bilangan Asam}

Secara umum, komponen utama minyak yang sangat menentukan mutu minyak adalah asam lemaknya, karena asam lemak menentukan sifat kimia dan stabilitas minyak [14].

Bilangan asam digunakan untuk mengukur jumlah asam lemak bebas yang terdapat dalam minyak atau lemak, serta untuk menentukan sifat kimia dan stabilitas minyak yang digunakan. Bilangan asam ditentukan dengan reaksi penyabunan, yaitu dengan cara mereaksikan minyak dan basa $\mathrm{KOH}$, seperti yang terdapat pada gambar berikut.

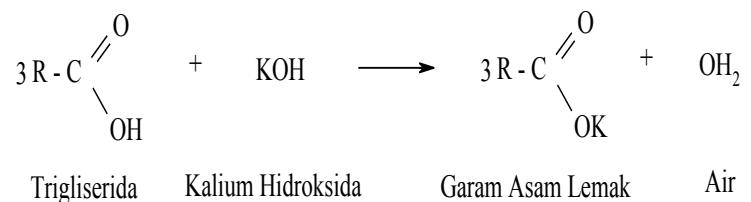

Gambar 6. Reaksi Penyabunan

Penentuan bilangan asam dilakukan dengan metode titrasi asam-basa berdasarkan perpindahan proton dan zat yang bersifat asam ke larutan yang bersifat basa [15]. Minyak yang akan diuji ditimbang 5 gram. Kemudian dicampurkan dengan $50 \mathrm{ml}$ alkohol 96\% sebagai pelarut minyak. Dipanaskan selama 10 menit dalam penangas air suhu $40^{\circ} \mathrm{C}$ sambil diaduk. Pengadukan bertujuan agar campuran menjadi lebih homogen, sehingga didapatkan kadar asam lemak yang semakin kecil. Hal ini menunjukkan semakin cepat waktu kontak, semakin banyak absorben mengkudu yang mengikat asam lemak bebas dan semakin tinggi pula penurunan kadar asam lemak bebas yang didapat. 
Campuran yang telah dipanaskan, ditetesi dengan indikator phenolptalein (pp) sebanyak 2 tetes. Selanjutnya dititrasi menggunakan larutan $\mathrm{KOH} 0.1 \mathrm{~N}$ sambil erlenmeyer digoyangkan hingga larutan berwarna merah muda. Larutan berwarna merah muda ini dikarenakan struktur dari indikator pp mengalami penataan ulang pada kisaran $\mathrm{pH}$ 8.4-10.4 sehingga proton akan dipindahkan dari struktur fenol yang menyebabkan pH-nya meningkat dan terjadi perubahan warna pada larutan yang dianalisa.

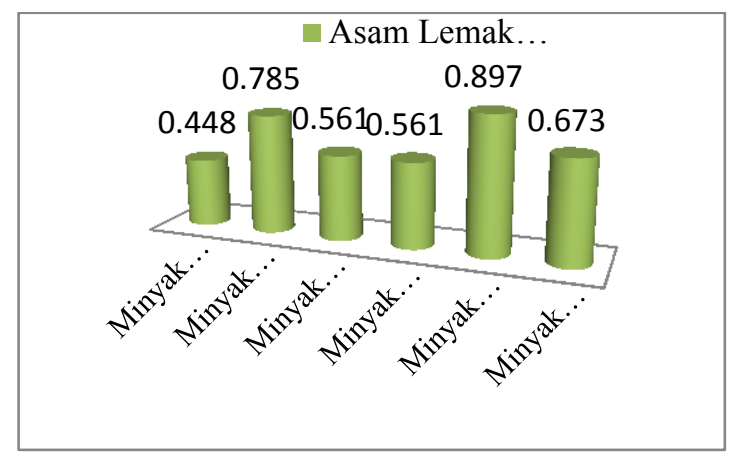

Gambar 7. Grafik Bilangan Asam

Tabel 2. Persen Penurunan Bilangan Asam

\begin{tabular}{|c|c|c|c|c|}
\hline \multirow[t]{2}{*}{ Sampel } & \multicolumn{2}{|c|}{ Kadar Air } & \multirow{2}{*}{$\begin{array}{c}\text { Penuru } \\
\text { nan }\end{array}$} & \multirow{2}{*}{$\begin{array}{c}\% \\
\text { Penuru } \\
\text { nan }\end{array}$} \\
\hline & $\begin{array}{c}\text { M. } \\
\text { Jelantah }\end{array}$ & $\begin{array}{c}\text { M. Jelantah + } \\
\text { Mengkudu }\end{array}$ & & \\
\hline $\begin{array}{l}\text { M. } \\
\text { Kemasan }\end{array}$ & 0.7854 & 0.561 & 0.2244 & 28.57 \\
\hline M. Curah & 0.8976 & 0.6732 & 0.2244 & 25.00 \\
\hline
\end{tabular}

Asam lemak bebas terbentuk karena proses oksidasi serta proses hidrolisis minyak yang disebabkan oleh air dengan katalis enzim atau panas pada ikatan ester trigliserida, seperti yang terdapat pada reaksi berikut.

Trigliserida $+\mathrm{OH}_{2} \stackrel{\text { Energi }}{\stackrel{\text { Panas }}{\longrightarrow}}$ Digliserida + Monogliserida + Asam Lemak

Keberadaan asam lemak bebas dalam minyak biasanya dijadikan indiator awal terjadinya kerusakan minyak karena proses hidrolisis. Asam lemak yang tinggi pada minyak goreng dapat menyebabkan keracunan pada tubuh manusia yang mengkonsumsinya dan menyebabkan kerusakan pada organ tubuh. Bilangan asam meningkat disebabkan terjadinya oksidasi pada minyak goreng selama proses penggorengan dengan suhu yang tinggi. Oksidasi ini menyebabkan terjadinya perubahan struktur kimia (dekomposisi) pada minyak goreng.

\section{E. Uji Organoleptik}

Uji organoleptik dilakukan untuk mengetahui tingkat kesukaan (warna, bau dan rasa) terhadap minyak jelantah yang telah dimurnikan dengan mengkudu yang diwakili oleh 25 panelis, 13 orang laki-laki dan 12 perempuan. Panelis yang berjumlah 25 orang ini termasuk ke dalam Panel tidak terlatih.

Panel tidak terlatih terdiri dari 25 orang awam yang dapat dipilih berdasarkan jenis suku-suku bangsa, tingkat sosial dan pendidikan. Panel tidak terlatih hanya diperbolehkan menilai alat organoleptik yang sederhana seperti sifat kesukaan. Untuk itu, panel tidak terlatih biasanya dari orang dewasa dengan komposisi panelis pria sama dengan panelis wanita [16].

Metode yang digunakan pada uji ini, yaitu metode hedonik (kesukaan). Uji hedonik merupakan salah satu jenis uji penerimaan. Dalam uji ini panelis diminta mengungkapkan tanggapan pribadinya tentang kesukaan atau sebaliknya ketidaksukaan [17].

Tingkat kesukaan terhadap warna, bau dan rasa yang dihasilkan dari sampel minyak kemasan, yaitu 99\%, $76 \%$ dan $89 \%$. Sedangkan sampel minyak curah, $99 \%$ dan $73 \%$.

\section{F. Analisis Angket}

Berdasarkan rekapitulasi angket kelayakan penelitian yang diberikan dalam bentuk video mengenai pemanfaatan mengkudu terhadap minyak jelantah, diperoleh jawaban sangat layak 1 guru dan jawaban layak 3 guru. Nilai komulatif yang didapatkan 27 , sedangkan yang diharapkan adalah 32 .

$$
\begin{aligned}
\text { Jadi, } \mathrm{P} & =\frac{F}{N} \times 100 \% \\
\mathrm{P} & =\frac{27}{32} \times 100 \% \\
\mathrm{P} & =84.375 \%
\end{aligned}
$$

Setelah dipersentasekan, maka hasil penilaian angket termasuk ke dalam kategori sangat baik 4. KESIMPULAN

Berdasarkan hasil penelitian dan pembahasan dapat diambil kesimpulan bahwa: 
a. Buah mengkudu memberikan manfaat terhadap minyak jelantah, ditandai dengan adanya penurunan bilangan asam, kadar air dan perubahan positif yang dihasilkan dari uji organoleptik.

b. Persentase penurunan bilangan asam minyak kemasan dan minyak curah dari minyak jelantahnya menjadi minyak hasil pemurnian, yaitu $28.57 \%$ dan $25 \%$. Sedangkan persentase penurunan kadar air dari masing-masing minyak berturut-turut adalah $75 \%$ dan $71.42 \%$.

c. Tingkat kesukaan terhadap warna, bau dan rasa yang dihasilkan dari sampel minyak kemasan, yaitu 99\%, $76 \%$ dan $89 \%$. Sedangkan warna dan bau yang dihasilkan dari sampel minyak curah, yaitu $99 \%$ dan $73 \%$.

d. Hasil angket tentang kelayakan video yang ditinjau dari segi isi dan penampilan, diperoleh nilai komulatif sebesar $84.375 \%$, termasuk ke dalam kategori sangat baik.

\section{SARAN}

Untuk penelitian selanjutnya, peneliti menyarankan agar menguji sifat fisik dan kimia lain, seperti uji bobot jenis, bilangan penyabunan dan bilangan peroksida dari minyak jelantah sebelum dan setelah pemurnian menggunakan mengkudu.

\section{REFERENSI}

[1] J. F. Pakpahan., et al. Pengurangan FFA dan Warna dari Minyak Jelantah dengan Adsorben Serabut Kelapa dan Jerami. Jurnal Teknik Kimia USU, Vol. 2, No. 1 (2013), h. 31.

[2] S. Mulyati, Meilina dan Hesti. Pemurnian Minyak Jelantah dengan Menggunakan Sari Mengkudu (2016, Januari 06). Laporan Penelitian. Fakultas Teknik Universitas Negeri Syiah Kuala (2006).

[3] N. Dewi. Budidaya, Khasiat dan Cara Olah Mengkudu untuk Mengobati berbagai Penyakit. Yogyakarta: Pustaka Baru Press, 2012, h. 53.

[4] M. Irwan, R. Thahir dan B. S. Kubro. Regenerasi Minyak Jelantah (Waste Cooking Oil) dengan Penambahan Sari Mengkudu. Jurusan Teknik Kimia Politeknik Negeri Samarinda. Riset \&
Teknologi /56 Media Perspektifi Vol. 10 Nomor 1, Juni 2010:1-59.

[5][8] Badan Standarisasi Nasional (BSN). SNI Minyak Goreng Nomor 3741:2013. Jakarta: BSNI.

[6] A. F. Ramdja, L. Febrina dan D. Krisdianto. Pemurnian Minyak Jelantah Menggunakan Ampas Tebu sebagai Adsorben. Jurnal Teknik Kimia, No. 1, Vol. 17, h. 10, 2010.

[7] Evika. Penggunaan Adsorben Arang Aktif Tempurung Kelapa pada Pemurnian Minyak Goreng Bekas. Pekanbaru: Skripsi Program Studi Pendidikan Kimia UIN SUSKA, 2011, h. 36.

[9] E. Yulia, A. H. Mulyati, F. Nuraeni. Kualitas Minyak Goreng Curah yang Berada di Pasar Tradisional di Daerah Jabotabek pada Berbagai Penyimpanan. Jurnal Program Studi Kimia, Fakultas Matematika dan Ilmu Pengetahuan Alam, Universitas Pakuan, $\mathrm{h} 4$

[10] D. P. Sari. Pengaruh Penambahan Dedak Padi terhadap Kadar Protein dan Sifat Organoleptik Tempe dari Biji Durian serta Diimplementasikan dengan Pengetahuan Siswa SMK Negeri 4 Pekanbaru. Pekanbaru: Skripsi Program Studi Pendidikan Kimia UIN SUSKA, 2015. h. 41.

[11] A. Sudijono. Pengantar Statistik Pendidikan. Jakarta: Raja Gravindo Persada, 2007, h. 43.

[12] A. Putra, S. Mahrdania, A. Dewi dan E. Saptia. Recovery Minyak Jelantah menggunakan Mengkudu sebagai Absorben. Prosiding Seminar Nasional PERTETA 2012, Malang, Jawa Timur, 30 November-2 Desember 2012.

[13][15] Chairunisa. Uji Kualitas Minyak Goreng pada Pedagang Gorengan di sekitar Kampus UIN Syarif Hidayatullah.Jakarta: Skripsi Fakultas Kedokteran dan Ilmu Kesehatan Program Studi Farmasi, 2013, h. 43 .

[14] F. G. Winarno. Minyak Goreng dalam Menu Masyarakat. Jakarta: Balai Pustaka, 1999, h. 118.

[16] Itsagusman. Modul Penanganan Mutu Fisis: Pengujian Organoleptik. Semarang: Program Studi Teknologi Pangan Universitas Muhammadiyah, 2013, h. 4.

[17] Tim Pengampuh Mata Kuliah. Penuntun Praktikum Evaluasi Sensori. Pekanbaru: Laboratorium Teknologi Pertanian Universitas Riau, 2015, h. 25. 